\title{
Chapter 4 \\ Teaching Culturally Diverse Student Groups in the Nordic Countries-What Can the TALIS 2018 Data Tell Us?
}

\author{
Julius K. Björnsson
}

\begin{abstract}
Almost all Nordic classrooms have some or a considerable number of students with a native language different from the language of instruction. Therefore, most Nordic teachers have to address the issues this setting imposes on them. The chapter is concerned with teachers' attitudes and experiences of teaching in a multicultural setting - that is, variations in their perceived self-efficacy in multicultural classrooms. The TALIS study is used to explore these effects and relate teacher experiences with the issues of equity and diversity. Our analysis includes all five Nordic countries. A linear regression approach was used, taking into account the multi-stage sampling in TALIS. The results indicate that general self-efficacy in teaching and not specific multicultural knowledge or experience has the most significant influence on the experienced ability to handle a multicultural setting. This is a somewhat surprising, albeit reassuring, result, as it indicates that a good and trustworthy teacher education and functional general teacher competencies are the most essential ingredients in adequately handling a multicultural classroom.
\end{abstract}

Keywords TALIS $\cdot$ Self-efficacy $\cdot$ Multicultural classrooms $\cdot$ Nordic countries

Empirical evidence demonstrates that compared to most other regions in the world, the Nordic region has achieved a considerable degree of equity and equality, with relatively small differences between the schools in these countries. However, socioeconomic status appears to have a comparably sized effect in the Nordic-as in most other-countries. Still, the Nordic schools seem to be able to counteract this effect and lift their socio-economically disadvantaged students (Agasisti, Avvisati, Borgonovi, \& Longobardi, 2018).

Within the context of the Nordic region, the so-called Nordic model has often been discussed in the literature (Imsen, Blossing, \& Moos, 2017; Klette, 2018;

\footnotetext{
J. K. Björnsson $(\bowtie)$

Department of Teacher Education and School Research, University of Oslo, Oslo, Norway

e-mail: j.k.bjornsson@ils.uio.no
} 
Veenis, 2014) exemplifying the idea of 'school for all.' Moreover, the view that the five Nordic countries have long been considered similar across many historical, economic and cultural strands, in addition to having comparable education systems, provided support in discussing the model. At the same time, under the auspice of neoliberal policies and trends, the Nordic systems have undergone some changes (Lundahl, 2016), which has led to an increase in differences within the Nordic arena. As an effect, it appears that some of the educational systems are less equitable than they used to be (Lundahl, 2016).

In light of these changing conditions in the Nordic countries, coupled with a considerable influx of immigrants and refugees (Karlsdottir, Norlen, Rispling, \& Randall, 2018) and increased mobility between countries of a different kind than in the past, inevitable changes have occurred to the education systems, affecting schools and teachers. Therefore, it has become highly relevant to follow both the achievements of these new citizens and how schools and teachers can accommodate and adapt to the changing conditions, especially since current research indicates that schools have a vital role in this process (Gustafsson, Nilsen, \& Hansen, 2016). Against this background, this chapter focuses on teachers' attitudes and beliefs about diversity in the classroom and their perception of how well they can teach in a multicultural classroom setting. In particular, the focus is on the factors related to the teaching profession, such as the experience of teaching, professional development and class characteristics, and how these factors affect teachers' perception of their own self-efficacy in a multicultural classroom. All five Nordic countries (i.e., Denmark, Finland, Iceland, Norway and Sweden) are examined using the data from the 2018 cycle of the Organisation for Economic Co-operation and Development (OECD) Teaching and Learning International Study (TALIS) (OECD, 2019a).

\subsection{Effective Teachers in Multicultural Classrooms}

In general, and now more than ever before, teachers need to have the ability to handle a complicated teaching environment (Kunter et al., 2013). In a situation where students come from culturally different backgrounds and many experience language disadvantages, combined with a job in which teachers also need to cater to the needs of special needs students in their classrooms, teaching competence is certainly being put to the test (Brante, 2009). If a teacher does not manage this complexity well and experiences not being able to handle this increased diversity, equity suffers with potentially long-term severe consequences for the students.

Research has underlined the importance of this ability to handle multicultural issues (Cushner \& Brennan, 2007), and it has been argued that teachers' interpersonal competence and ability to adapt to the different ethnic origins of their students is a crucial factor in achieving optimal learning outcomes in a multicultural setting (Wubbels, den Brok, Veldman, \& van Tartwijk, 2006). If the teacher is aware of and 
has a positive attitude towards students from different cultural backgrounds, he/she appears to be more able to create a positive classroom atmosphere and meet the diverse needs of the students. Therefore, optimal results in multicultural classrooms appear to be dependent on a few essential factors, which include monitoring and managing student behaviour, creating positive teacher-student (and peer) relationships, teaching for student attention and engagement and the attitudes and specific knowledge about multiculturality the teacher needs to possess.

The first three factors are usually included in a variety of conceptualisations of teacher effectiveness (e.g., Hamre et al., 2013), while the fourth addresses specifically multicultural issues and attitudes (Wubbels et al., 2006). Hamre et al. (2013) provide one such example of a general model, which comprises emotional support, classroom organisation and instructional support. Each of the three constructs is further broken into several different aspects. Emotional support includes positive climate, negative climate, teacher sensitivity and regard for student perspectives and overcontrol. Classroom organisation consists of behavioural management, instructional learning formats, productivity and chaos. Instructional support comprises concept development, quality of feedback, language modelling and richness of instructional methods (Hamre et al., 2013). Models like this are complex and multifaceted, pulling together many different but related concepts, conceptualisations and behaviours, although most of them do not include multicultural aspects or specify how the general factors interact with multiculturality.

Such models have been linked to student performance and have revealed that teachers that score high on all these aspects tend to have students that perform better and show more progress (Stronge, Ward, \& Grant, 2011). Using a hierarchical linear model, Stronge et al. (2011) showed that there were differences between the teachers who were the most and least effective on their students' performance. The effective teachers experienced less student disruptive behaviour and better interactions with their students and had better classroom management and personal qualities. No significant differences were found across different instructional or assessment methods.

Specific instruments have been developed to measure teacher effectiveness and capacity to handle a multicultural situation (Spanierman et al., 2011). Such instruments focus on what teachers do in these situations, illustrating that without a positive attitude to multiculturalism, quality teaching suffers. Therefore, teachers' attitudes towards handling these issues and their perception of their own ability to handle the variety of these diversities - which are common in most classrooms today-are of paramount importance. Research so far indicates that these perceptions and experiences may go hand in hand with teachers' increased competence in teaching minority students and increased positive attitudes towards such student groups (Glock, Kovacs, \& Pit-ten Cate, 2019). Moreover, research has shown that teacher beliefs and attitudes influence students. Geerlings, Thijs, and Verkuyten (2019) recently studied how teacher norms about cultural diversity and practices interact to affect students' perspectives and how these effects differed for minority and majority students. The data from the study included Dutch, Turkish-Dutch and Moroccan-Dutch students from the fourth to sixth grades. The results showed that 
all students tend to have a more positive attitude towards ethnic groups when they perceive their teacher doing so. This made clear that students in multicultural classrooms are highly influenced by both their teacher's beliefs and installed classroom practices.

While teacher effectiveness can be conceptualised in many ways, most authors include in the definition of teachers' ability to maintain proper classroom management, students' cognitive activation and the fostering of a supportive climate for all students (Fauth, Decristan, Rieser, Klieme, \& Büttner, 2014; Kunter et al., 2013). However, teacher attitudes towards and specific knowledge about multicultural issues are most often not included in these definitions. Given the diversity teachers face in their everyday practice, the ability to handle multicultural situations should become part of such conceptualisations. In this way, we ensure and increase our understanding of what makes teachers stay effective in a multicultural setting (Au \& Raphael, 2000).

\subsection{Equity and Classroom Diversity in the Nordic Countries}

Changes in the Nordic school systems with increasing diversity, an increased number of students with diversified cultural backgrounds and the changes in policies in some of the countries-especially Sweden and Norway-may lead to reduced equity and equality in the Nordic schools. Large-scale international studies, such as Trends in International Mathematics and Science Study (TIMSS) and Programme for International Student Assessment (PISA), have shown that diversity increases over time considering the increased numbers of immigrant students and variation in socioeconomic status, perhaps especially in Sweden (OECD, 2018b). These changes appear to be closely linked to policy changes (Lundahl, 2016) and the amount of immigration in each country (Karlsdottir et al., 2018), which also varies considerably.

Handling increased student diversity goes hand in hand with the question of how different education systems are able to cater to the needs of such students and the extent to which they are offered equal chances to succeed within the system. Within this context, equity and equality are two terms that are often somewhat interchangeably used in the education literature (Espinoza, 2007, see Chap. 2 in this volume for a further discussion). The mixing up of the two terms is noticeable even in the OECD's extensive report on equity in education (OECD, 2018a). The report starts by stating how 'equity in education means that schools and education systems provide equal learning opportunities to all students' (p.13), a statement which is clearly about equality, not equity. The report goes on with elaborating that 'equity does not mean that all students obtain equal education outcomes, but rather that differences in students' outcomes are unrelated to their background or to economic and social circumstances over which students have no control'. Therefore, despite its extensiveness, the equity-equality paradigm is observed through the relationship between educational achievement and socioeconomic status, clearly indicating that the 
difference between equity and equality requires further elaboration. Espinoza's (2007) conceptualisation deepens and clarifies this dichotomy by viewing the particular contributions schools may have on the equality and equity continuum in a more varied way. From the stance of multicultural classrooms in particular and how well teachers cater to student diversity, very much connects to his idea of access to education quality, in the sense that all students having equal abilities will gain such access (i.e., equity for equal potential) and will not be constrained by coming from diverse backgrounds (i.e., equality of opportunity).

Although labelled in a somewhat different fashion, the idea of access to quality instruction is very much a central component of the TALIS (OECD, 2019a). Within the TALIS framework, two main perspectives can be recognised: first, the perspective of how to increase equity in schools, by integration or fostering equality and inclusion and valuing diversity in the classroom, and second, by evaluating the socalled 'multiculturalism', which means that schools should acknowledge that differences in culture can and will enrich student life (Ainley \& Carstens, 2018). Additionally, TALIS is concerned with teaching and learning in socioeconomically diverse groups of students, an aspect strongly connected to the first two.

The TALIS conceptualisation of equity underlines the complexity of the concept, interlinking the issues of equity and cultural diversity, which touch on most-if not all-aspects of teaching and learning. This is especially true in Europe where migration is an ever-increasing factor when considering equity in schools and education and when evaluating the effects of migration on children and their situation (Moskal $\&$ Tyrrell, 2015). These two themes, equity and diversity, are naturally closely linked, as equity issues become more important to a larger number of students with increasing heterogeneity. The TALIS 2018 framework further defines different sources of diversity. Among others, these include socioeconomic diversity, cultural diversity and gender. Equity issues connected to changes in all these areas require knowledge about school policies, teaching practices and approaches to teaching, and touch upon most, if not all, aspects of the organisation of teaching and learning.

Important information on the changes over time concerning diverse equality and equity issues across all the Nordic countries can be found in the results from the TALIS. The study focuses on the attitudes and beliefs of teachers and principals concerning many aspects of their profession. Among other things, it explores how well teachers and school leaders experience that they are able and willing to handle the increasing cultural diversity in schools. As to the Nordic countries, the data has shown considerable changes in the composition of the student body in the three completed study cycles and that immigrant students or students from different cultural backgrounds are now a large and significant part of the Nordic classrooms. Table 4.1 illustrates the situation in the Nordic countries concerning having a native language other than the language of instruction, as per the TALIS 2018.

These numbers indicate that most schools have many students who need specialised instruction and additional language support, with Sweden having the highest percentage of such students. The numbers also indicate that there is a number of schools in the Nordic countries where there are no such students. Denmark is an exception, since almost all Danish schools have students that speak a language at 
Table 4.1 Percentage of schools with students having a different language than the language of instruction (from the Principal questionnaire in the TALIS 2018)

\begin{tabular}{l|l|l}
\hline Country & $\begin{array}{l}\text { Percentage of schools with more than 10\% } \\
\text { of students that speak a different language } \\
\text { than the language of instruction }\end{array}$ & $\begin{array}{l}\text { Percentage of schools with no students } \\
\text { that speak a different language than the } \\
\text { language of instruction }\end{array}$ \\
\hline Denmark & 25 & 3 \\
\hline Finland & 17 & 14 \\
\hline Iceland & 34 & 11 \\
\hline Norway & 17 & 14 \\
\hline Sweden & 46 & 13 \\
\hline
\end{tabular}

home that is different than the language of instruction. Therefore, there are considerable differences between the systems observed, and these numbers also indirectly indicate that there is a clustering of immigrant students in certain schools in all five countries.

However, when looking more closely at the teachers in these schools, a somewhat different picture emerges. In 2018, teachers answering the TALIS questionnaire indicated that in almost $90 \%$ of the cases, they are teaching a class with some or many special needs students, including those with language difficulties. Furthermore, on average, $77 \%$ of the Nordic teachers indicated that they have some experience teaching students with a different cultural background, the highest percentage (86\%) being in Sweden (OECD, 2019a). Therefore, it is clear that cultural and other kinds of diversity are widespread in the Nordic school systems and are continually growing more substantial and becoming a feature of most classes in the Nordic schools. A more detailed table based on the teachers' evaluation can be found in the Appendix.

\subsection{Aim of the Chapter}

The short review above underlines the fact that multicultural attitudes and teacher self-perception in dealing with a multicultural classroom are important aspects of overall teacher efficacy in providing quality instruction to all students. It is therefore of considerable importance to examine how Nordic teachers experience this changing situation and how they perceive themselves in addressing a multicultural setting in the classroom. Given earlier research that Nordic schools in general seem to be able to counteract the negative effects of student diversity (Agasisti et al., 2018), it is essential to investigate these perceptions across all five countries. The TALIS data, with their international perspective, can aid in examining the extent to which such perceptions are uniform or not.

Therefore, the aim of this chapter is to investigate the variations in self-efficacy in multicultural classrooms among Nordic teachers and to identify whether particular aspects of teacher background can predict that variation. The chapter explores whether the perception of teachers' self-efficacy in a multicultural setting has a 
two-level component- that is, if teachers from different schools are meaningfully different in their perception of their own self-efficacy. Such differences could indicate that different school policies or practices influence teachers in different ways. With the increasing diversity in schools across the Nordic countries, this could be an essential feature of local school policies, leading to differences between schools (Klette, 2018).

\subsection{Methods}

The current investigation uses data from the TALIS. Implemented in 48 countries, this study was initiated by the OECD and was in its last cycle in 2018. The TALIS provides a detailed questionnaire for teachers and school principals, administered online. The study was conducted twice before the 2018 cycle, in 2008 and 2013. All additional information regarding the study can be found in the TALIS framework (Ainley \& Carstens, 2018) and the accompanying technical report (OECD, 2019b).

All questionnaires were administered to lower secondary (ISCED 2) teachers and school principals in all the participating countries, although some countries added the same or similar questionnaires to either or both ISCED 1 (primary schools) and ISCED 3 (upper secondary schools), resulting in three populations in these countries. In this chapter, only data from lower secondary schools (ISCED 2) from Denmark, Finland, Iceland, Norway and Sweden are examined.

The TALIS uses a stratified two-stage probability sampling design (OECD, 2019b), which sampled schools primarily; a sample of teachers was subsequently drawn from each selected school. Information on the number of schools and teachers in the final sample from the five Nordic countries is provided in Table 4.2.

\subsubsection{Variables}

The TALIS aims to deliver information on teachers' instructional and professional practices, school leadership, teachers' initial education and initial preparation, teacher feedback and development, school climate, job satisfaction and motivation, teacher human resource measures and stakeholder relations, teacher self-efficacy, innovation and, finally, equity and diversity.

In addition to the individual questionnaire items, the TALIS database includes a number of scales and indices, which can be divided into two types. The first are

Table 4.2 The final number of ISCED-2 participating schools and teachers in the Nordic countries

\begin{tabular}{l|l|l|l|l|l}
\hline & Denmark & Finland & Iceland & Norway & Sweden \\
\hline No. of schools & 141 & 148 & 122 & 185 & 180 \\
\hline No. of teachers & 2001 & 2850 & 1276 & 4153 & 2779 \\
\hline
\end{tabular}


simple summary indices, such as the number of years of teaching experience, the number of different teaching assignments, etc. By contrast, the second type comprises more complex indices (i.e., latent variables), constructed with confirmatory factor analysis (CFA), where an integral part of the scale construction is invariance testing. This is a highly important aspect of the scales, as cultural differences can certainly influence the teachers' answers heavily and possible cultural bias must be accounted for before using the constructs for between-country comparisons. All these indices are based on different questions on the same or related themes. They were all tested for adequate model fit and reliability and finally transformed into a standardised format for inclusion in the final database. All the constructs were based on three or more items (OECD, 2019b).

Almost none of the scales constructed for the ISCED-2 sample (with one exception, innovation) are scalar invariant; therefore, their values or averages cannot be directly compared across countries. However, most of them fulfil the criteria for metric invariance, rendering the results from separate analyses from each included country comparable. The analysis performed here adheres to this and was done separately for each of the five Nordic countries.

The initial analysis included multiple constructs. Three are simple summary indices, namely teacher age and teacher experience, measured in number of years, and an index reflecting the sum of diversity in the teacher's class. The latter is a simple construct addressing diversity in the composition of the target class. The teachers were asked about the proportion of students with a first language different from the language of instruction, low academic achievers in the class, special needs students, students with behavioural problems, students from socio-economically disadvantaged homes, academically gifted students, immigrant students and students who are refugees. The sum of all the answers is a measure of the classroom diversity. All other indices belong to the complex group. These include teaching and professional practices, teachers' motivation, feedback and development, teachers' self-efficacy, job satisfaction, work stress and well-being, school climate, equity and diversity and team innovativeness. Table 4.3 provides a comprehensive overview of these constructs. For more details, see the TALIS technical report (OECD, 2019b).

A backward stepwise regression analysis (OLS-ordinary least squares) was used in the initial analyses including all the described variables. At each step, the variables and indices having a non-significant relationship with self-related efficacy in multicultural classrooms (the dependent variable) were removed from the model. The model was rerun for each country until there were 11 variables and indices left, all of which were significantly related to the dependent variable, self-related efficacy (SEFE) in multicultural classrooms, in at least one of the countries observed in the analyses. Table 4.4 provides descriptive information on the constructs included in the final analysis. 
Table 4.3 Complex indices included in the initial analysis

\begin{tabular}{|c|c|}
\hline Scale & Description \\
\hline $\begin{array}{l}\text { Teaching } \\
\text { practices-overall }\end{array}$ & $\begin{array}{l}\text { A composite scale on teaching practices with three subscales, } \\
\text { comprising } 12 \text { items in total; the subscales include: } \\
\text {-clarity of instruction ( } 4 \text { items on how one teaches, what a teacher does), } \\
\text {-classroom management ( } 4 \text { items on how the class is managed, rules, } \\
\text { listening and managing disruptions) and } \\
\text {-cognitive activation ( } 4 \text { items on teaching methods, tasks, critical } \\
\text { thinking, group work). }\end{array}$ \\
\hline $\begin{array}{l}\text { Teacher } \\
\text { cooperation—overall }\end{array}$ & $\begin{array}{l}\text { A composite scale comprising } 10 \text { items with two subscales: } \\
\text {-professional collaboration in lessons ( } 5 \text { items describing cooperation } \\
\text { among teachers in classrooms) and } \\
\text {-exchange and cooperation among teachers ( } 5 \text { items describing } \\
\text { collaboration among teachers in the school). }\end{array}$ \\
\hline $\begin{array}{l}\text { Teacher motivation } \\
\text { and perceptions }\end{array}$ & $\begin{array}{l}\text { A composite scale comprising } 10 \text { items, including the following } \\
\text { subscales: } \\
\text {-personal utility value of teaching ( } 4 \text { items on why teaching was chosen } \\
\text { as a career), } \\
\text {-social utility value of teaching ( } 3 \text { items on how teaching allows one to } \\
\text { benefit society) and } \\
\text {-perceptions of value and policy influence ( } 3 \text { items on how others value } \\
\text { teachers). }\end{array}$ \\
\hline $\begin{array}{l}\text { Feedback and } \\
\text { development }\end{array}$ & $\begin{array}{l}\text { A composite scale comprising } 8 \text { items with two subscales: } \\
\text {-effective professional development ( } 4 \text { items on the quality of } \\
\text { professional development) and } \\
\text {-teachers' need for professional development for diversity ( } 4 \text { items on } \\
\text { teaching individual learning, training in special needs teaching and } \\
\text { teaching in multicultural settings). }\end{array}$ \\
\hline $\begin{array}{l}\text { Teacher } \\
\text { self-efficacy—overall }\end{array}$ & $\begin{array}{l}\text { A composite scale comprising } 12 \text { items with three subscales: } \\
\text {-self-efficacy in classroom management (4 items on what the teacher } \\
\text { does in the classroom), } \\
\text {-self-efficacy in instruction ( } 4 \text { items about questions for the students, } \\
\text { assessment strategies, explanations and instructional variety) } \\
\text {-self-efficacy in student engagement (4 items on influencing students' } \\
\text { beliefs, attitudes and motivation). }\end{array}$ \\
\hline Job satisfaction & $\begin{array}{l}\text { A composite scale of } 13 \text { items with three subscales: } \\
\text {-job satisfaction with work environment ( } 4 \text { items on working at school), } \\
\text {-job satisfaction with profession ( } 4 \text { items on the advantages and choice } \\
\text { to become a teacher) and } \\
\text {-satisfaction with target class autonomy ( } 5 \text { items on to which extent the } \\
\text { teacher has control over their teaching methods). }\end{array}$ \\
\hline $\begin{array}{l}\text { Work stress and } \\
\text { well-being }\end{array}$ & $\begin{array}{l}\text { A composite scale comprising } 12 \text { items, with the following subscales: } \\
\text {-workplace well-being and stress ( } 4 \text { items on stress and how it affects } \\
\text { other } \\
\text { things and well-being generally), } \\
\text {-workload stress ( } 5 \text { items on having too much to do in many areas) and } \\
\text {-student behaviour stress ( } 3 \text { items describing stress connected to } \\
\text { classroom } \\
\text { management, difficult students, and being responsible for student } \\
\text { achievement). }\end{array}$ \\
\hline
\end{tabular}


Table 4.3 (continued)

\begin{tabular}{|c|c|}
\hline Scale & Description \\
\hline School climate & $\begin{array}{l}\text { A composite scale of } 13 \text { items, with the following subscales: } \\
\text {-teachers' perceived disciplinary climate ( } 4 \text { items on what happens in } \\
\text { the lessons), } \\
\text {-teacher-student relations ( } 4 \text { items on whether the teacher gets along } \\
\text { with the students, is interested in them and provides them with help) and } \\
\text {-participation among stakeholders ( } 5 \text { items on what the school provides } \\
\text { for the collaboration between teachers, parents and students). }\end{array}$ \\
\hline Equity and diversity & $\begin{array}{l}\text { A composite scale comprising } 9 \text { items with two subscales: } \\
\text {-self-related efficacy in multicultural classrooms ( } 5 \text { items on how well } \\
\text { the teacher perceives their own ability to handle multicultural } \\
\text { classrooms) and } \\
\text {-diversity practices ( } 4 \text { items on what the teacher specifically does in a } \\
\text { multicultural situation). }\end{array}$ \\
\hline Team innovativeness & $\begin{array}{l}\text { Four items on how the teachers and the school develop new ideas and } \\
\text { methods. }\end{array}$ \\
\hline
\end{tabular}

Table 4.4 Variables included in the final analysis

\begin{tabular}{|c|c|c|c|c|c|c|c|c|c|c|c|}
\hline \multirow[b]{2}{*}{ Variable } & \multirow[b]{2}{*}{ Type } & \multicolumn{2}{|c|}{ Denmark } & \multicolumn{2}{|c|}{ Finland } & \multicolumn{2}{|c|}{ Iceland } & \multicolumn{2}{|c|}{ Norway } & \multicolumn{2}{|c|}{ Sweden } \\
\hline & & Avg & SD & Avg & SD & Avg & SD & Avg & SD & Avg & SD \\
\hline $\begin{array}{l}\text { Experiences as a teacher } \\
\text { (years) }\end{array}$ & Simple & 15.2 & 10.0 & 15.8 & 9.5 & 15.0 & 10.4 & 14.7 & 10.5 & 15.5 & 9.9 \\
\hline Age (years) & Simple & 44.4 & 10.4 & 44.8 & 9.8 & 46.2 & 10.5 & 43.8 & 11.2 & 45.7 & 10.4 \\
\hline Sum of diversity in class & Simple & 17.9 & 4.1 & 16.9 & 4.2 & 17.9 & 4.0 & 18.2 & 3.9 & 20.0 & 4.9 \\
\hline Workload stress & Construct & 9.2 & 2.6 & 9.2 & 1.4 & 9.2 & 2.0 & 9.2 & 1.8 & 9.2 & 1.9 \\
\hline $\begin{array}{l}\text { Teaching } \\
\text { practices-overall }\end{array}$ & Construct & 11.5 & 2.0 & 11.5 & 2.0 & 11.5 & 2.0 & 11.5 & 1.8 & 11.5 & 1.9 \\
\hline $\begin{array}{l}\text { Teacher-student } \\
\text { relations }\end{array}$ & Construct & 13.3 & 1.8 & 13.3 & 1.9 & 13.3 & 1.9 & 13.3 & 1.8 & 13.3 & 1.9 \\
\hline $\begin{array}{l}\text { Social utility value of } \\
\text { teaching }\end{array}$ & Construct & 12.2 & 2.1 & 12.2 & 2.6 & 12.2 & 2.7 & 12.2 & 2.3 & 12.2 & 2.4 \\
\hline Teacher self-efficacy & Construct & 12.7 & 1.6 & 12.7 & 2.24 & 12.7 & 2.0 & 12.7 & 1.5 & 12.7 & 1.9 \\
\hline $\begin{array}{l}\text { Needed professional } \\
\text { development for } \\
\text { diversity }\end{array}$ & Construct & 9.9 & 1.9 & 9.9 & 2.0 & 9.9 & 2.2 & 9.9 & 2.0 & 9.9 & 2.5 \\
\hline Job satisfaction & Construct & 12.0 & 2.1 & 12.0 & 2.1 & 12.0 & 2.0 & 12.0 & 2.0 & 12.0 & 2.2 \\
\hline Disciplinary climate & Construct & 8.7 & 1.9 & 8.7 & 2.3 & 8.7 & 2.0 & 8.7 & 2.0 & 8.7 & 2.3 \\
\hline $\begin{array}{l}\text { Self-related efficacy in } \\
\text { multicultural classrooms } \\
\text { (dependent variable) }\end{array}$ & Construct & 11.2 & 1.6 & 11.2 & 1.8 & 11.2 & 2.4 & 11.2 & 1.8 & 11.2 & 1.8 \\
\hline
\end{tabular}

Note that the averages are the same for the complex CFA constructs in the table, as they reached only metric invariance and were standardised for each country. However, the SD of the constructs differs between the countries 


\subsection{Data Analysis}

The data used in this study were analysed and handled with SPSS and the IDB Analyzer from IEA (IEA, 2019) using teacher weights and the 100 replicate weights of the TALIS (i.e., Balanced Repeated Replication [BRR]), thus taking into account the two-stage sampling. The backward stepwise regression was done separately for each country. The two-level regression analyses were performed for each Nordic country separately with Mplus 8 (Muthén \& Muthén, 1998-2017). Only the variables that had a significant relationship to SEFE in one or more of the five countries were included in the final model.

Missing data. Before any analysis, the data were checked for missingness. For the indices related to a work situation in general, the amount of missing answers was rather low across all the Nordic countries. For example, the amount of missing answers on professional development was $6 \%$ on average, while the index on job satisfaction was also about the same. However, when it came to the cultural diversity scales, the situation was very different. For the dependent variable in this analysis, the index of self-rated efficacy in multicultural classrooms, over $29 \%$ of the answers on average across the Nordic countries were missing, with Iceland having 40,6\% missing and the lowest being Sweden and Finland, with about 23\% missing on these questions. Table 4.5 shows the missing percentage of SEFE in each country.

The statistical modelling of the constructs (i.e., Structural Equation ModellingSEM and Confirmatory Factor Analysis-CFA) takes into account the missing values using a model-based approach to estimating them (OECD, 2019b). Thus, the model makes it possible to use data from all the countries, assuming that the data are missing at random (MAR) — an aspect which should not be overlooked when interpreting the results.

In addition to this, all the simple and complex scales were inspected for missing data in age, gender and teacher experience. Age shows a more substantial amount of missing answers only in Norway in the age group 25-29 and a smaller amount in the 60+ age group in Finland. No differences between age groups are observed for Denmark. As to gender, the number of missing values revealed no significant differences between males and females: $25 \%$ of females and $28 \%$ of males had missing values across the countries overall. Concerning the total experience as a teacher in these five countries, they all had a similar mean length of experience, about 15.2 years. Variation between the countries was almost non-existent. Furthermore, there is no increase or decrease in the number of missing values according to the length of experience as a teacher; the pattern appears to be mostly random, so the MAR assumption of the SEM modelling appears to be upheld.

Table 4.5 Percentage of missing answers on the index of self-efficacy in multicultural classrooms

\begin{tabular}{l|l|l|l|l}
\hline Denmark & Finland & Iceland & Norway & Sweden \\
\hline 35.7 & 22.7 & 40.6 & 25.5 & 22.4 \\
\hline
\end{tabular}




\subsection{Results}

This section will first describe the two-level regression model and follow with the one-level models. The two-level model was tested first in order to ascertain whether such a model was necessary.

\subsubsection{The Two-Level Model}

Because of the two-stage sampling employed in the TALIS and the possibility of a school-level influence (i.e., between level variance), a two-level regression analysis was carried out (Geiser, 2013). For this purpose, a null model checking the intraclass correlation (ICC) of the SEFE variable was obtained. This analysis indicates whether teachers' multicultural self-efficacy has a significant between-schools component.

The data in Table 4.6 indicate an inconsistent level of ICC in the five countries. The ICC is higher than 0.05 only in Sweden and Norway, indicating that only these two countries have significant differences between schools when controlling for variability among the teachers.

The predictor variables used in a further two-level regression analysis were all the indices and constructs described earlier, with the analysis performed separately for each country. However, none of these variables were significant at the school level, not even in Norway and Sweden when looking at their relationship with SEFE. Therefore, this type of analysis was not pursued further, and a conventional OLS one-level backward stepwise regression analysis was conducted as described earlier.

\subsubsection{One-Level Models}

The one-level multiple regression analysis performed separately for each country yielded the results shown in Table 4.7. All the TALIS constructs described earlier were initially included in the model. However, in the final analysis, we included only those with a significant relation to SEFE in one or more of the five examined countries. The final analysis estimated the exact same model in all five countries.

This regression analysis result shows the relation between the teachers' perceived competence to handle multicultural classrooms and students and the variables that contribute to its prediction. All the shown coefficients are significant at

Table 4.6 Intra-class correlations for self-efficacy in multicultural classrooms

\begin{tabular}{l|l|l|l|l|l}
\hline & Denmark & Finland & Iceland & Norway & Sweden \\
\hline ICC & 0.038 & 0.023 & 0.033 & 0.073 & 0.093 \\
\hline
\end{tabular}


Table 4.7 Multiple regression analysis of self-reported efficacy in multicultural classrooms

\begin{tabular}{|c|c|c|c|c|c|}
\hline & Denmark & Finland & Iceland & Norway & Sweden \\
\hline $\begin{array}{l}\text { Experiences as a teacher-total } \\
\text { (years) }\end{array}$ & $\begin{array}{l}-0.11 \\
(0.05)\end{array}$ & $\begin{array}{l}-0.10 \\
(0.04)\end{array}$ & $\begin{array}{l}-0.11 \\
(0.05)\end{array}$ & $\begin{array}{l}-0.08 \\
(0.03)\end{array}$ & $\begin{array}{l}-0.13 \\
(0.03)\end{array}$ \\
\hline Age (years) & ns & $\begin{array}{l}0.13 \\
(0.04)\end{array}$ & ns & ns & ns \\
\hline Workload stress & ns & ns & $\begin{array}{l}-0.15 \\
(0.04)\end{array}$ & $\begin{array}{l}-0.05 \\
(0.02)\end{array}$ & $\begin{array}{l}-0.06 \\
(0.02)\end{array}$ \\
\hline Teaching practices_overall & $0.11(0.04)$ & $\begin{array}{l}0.16 \\
(0.03)\end{array}$ & $0.09(0.05)$ & $\begin{array}{l}0.15 \\
(0.02)\end{array}$ & $\begin{array}{l}0.14 \\
(0.03)\end{array}$ \\
\hline Teacher-student relations & ns & $\begin{array}{l}0.06 \\
(0.03)\end{array}$ & $0.09(0.04)$ & $\begin{array}{l}0.06 \\
(0.02)\end{array}$ & $\begin{array}{l}0.07 \\
(0.03)\end{array}$ \\
\hline Social utility value of teaching & $0.08(0.03)$ & $\begin{array}{l}0.10 \\
(0.03)\end{array}$ & ns & $\begin{array}{l}0.10 \\
(0.02)\end{array}$ & $\begin{array}{l}0.09 \\
(0.03)\end{array}$ \\
\hline Teacher self-efficacy—overall & $0.27(0.03)$ & $\begin{array}{l}0.23 \\
(0.02)\end{array}$ & $0.29(0.04)$ & $\begin{array}{l}0.23 \\
(0.02)\end{array}$ & $\begin{array}{l}0.24 \\
(0.03)\end{array}$ \\
\hline $\begin{array}{l}\text { Needed professional } \\
\text { development for diversity }\end{array}$ & $\begin{array}{l}-0.10 \\
(0.03)\end{array}$ & ns & ns & $\begin{array}{l}-0.09 \\
(0.02)\end{array}$ & $\begin{array}{l}-0.10 \\
(0.02)\end{array}$ \\
\hline Job satisfaction & ns & $\begin{array}{l}0.05 \\
(0.02)\end{array}$ & ns & ns & $\begin{array}{l}0.05 \\
(0.02)\end{array}$ \\
\hline Disciplinary climate & ns & ns & ns & $\begin{array}{l}-0.07 \\
(0.02)\end{array}$ & ns \\
\hline Sum of diversity in class & $0.08(0.03)$ & $\begin{array}{l}0.14 \\
(0.03)\end{array}$ & $0.08(0.04)$ & $\begin{array}{l}0.15 \\
(0.02)\end{array}$ & $\begin{array}{l}0.17 \\
(0.02)\end{array}$ \\
\hline R-square & $0.15(0.02)$ & $\begin{array}{l}0.20 \\
(0.02)\end{array}$ & $0.19(0.03)$ & $\begin{array}{l}0.19 \\
(0.02)\end{array}$ & $\begin{array}{l}0.22 \\
(0.02)\end{array}$ \\
\hline
\end{tabular}

Note. Displayed coefficients are significant at $\mathrm{p}<=0.05$

Standardised regression coefficients, (Standard Error) in parenthesis

the 0.05 level in at least one of the countries, while the non-significant coefficients are not displayed. The shared model explains between 15 and $22 \%$ of the total variation in self-efficacy in multicultural classrooms, which is a sizeable proportion. The explanatory value was 15\% in Denmark, 20\% in Finland, 19\% in Iceland and Norway and $22 \%$ in Sweden.

When observing the contributions from the different variables independently, the most significant predictor across all the countries is teachers' overall self-efficacy, with the markedly highest relation to SEFE. Still, teaching practices, the amount of diversity in the classroom, and the length of experience as a teacher are all variables that have a similar effect in all the countries, allowing for observing some common patterns. It must be noted that length of experience as a teacher has a negative relation to the perceived multicultural attitudes.

It is also interesting to note that more of the variables shown in the table are more significant in Norway and Sweden than in the other three countries. In most cases, the regression coefficients depict a 'logical' relationship to the SEFE variable, with rather small differences between the countries. However, there is one exceptionlength of experience being a teacher-which has a negative relationship to SEFE. 
Workload stress has a considerably larger relation to SEFE in Iceland than in Norway and Sweden, while it does not seem to affect teachers' SEFE in Denmark and Finland. Age is another variable that only has a relation to SEFE in Finland but appears to be unrelated to SEFE in all the other countries. Teacher-student relations have a similar effect in four countries, except Denmark. The social utility value of teaching is positively related to SEFE in all the countries, except for Iceland. And, interestingly, the multicultural attitudes of teachers in Finland and Iceland have no relation to their need for more multicultural professional development. Last, job satisfaction is significant only in Finland and Sweden, while Norway is the only country with a negative relationship between SEFE and class disciplinary climate. Therefore, although the coefficients are small, all these variables underline some differences between the countries.

\subsection{Discussion}

All the descriptive information on equity and diversity presented here indicates that the multicultural attitudes of Nordic teachers are in some respects quite similar, a finding well aligned with the guiding concepts of the Nordic school model (Veenis, 2014). At the same time, clear differences are also observable, especially in Sweden-which might be expected since the country has the highest number of recent immigrants and refugees (Statistics Norway ${ }^{1}$ ). Surprisingly, Iceland also has a large number of students with potential language barriers. Still, one issue concerning any comparison is whether these large groups of students from different cultures are comparable across these countries at all. This is probably not the case, as Sweden, for example, has a large number of recent refugees from the Middle East, while Iceland has mostly work-related immigrants, primarily from eastern European countries. These differences in the type of immigrants are not reflected in the TALIS data but are a concern and become important when trying to understand the difficulties connected to integrating these students in the Nordic schools (Karlsdottir et al., 2018). This means that even though the Nordic school systems are similar, there are differences in the student body not reflected in the TALIS database. The TALIS questions do not differentiate between, for example, immigrants that are refugees from wars and hardship and those that come from more peaceful circumstances but are immigrating to increase their standard of living. Future studies focusing on these nuances are therefore needed.

When looking at the results from the regression analysis, it is-perhaps not surprisingly - apparent that the one variable having the largest impact is general selfefficacy in teaching. This is a composite index consisting of self-efficacy in classroom management, instruction and student engagement. Therefore, this is a broad measure of teacher self-efficacy but does not include the ability to handle

\footnotetext{
${ }^{1}$ https://www.ssb.no/befolkning/statistikker/innvbef/aar
} 
multicultural classes or attitudes towards multiculturalism. In other words, if a teacher is generally competent and their experience is that they can handle most teaching situations well, they are probably also comfortable in a multicultural setting and will perceive themselves as able to handle such circumstances adequately. This conclusion is partially upheld in the literature, where teachers with high teacher self-efficacy have been shown to do better with minority students that others (Jenkins-Martin, 2014). Furthermore, recent studies indicate the importance of positive attitudes towards multicultural students where this appears to enhance learning (Sela-Shayovitz \& Finkelstein, 2020).

General self-efficacy in teaching appears to be highly comparable and similar across the Nordic countries and is the most important variable in the whole regression analysis. Age does not influence this relationship, except in Finland where increased age (and therefore, presumably experience) appears to have a positive effect. However, experiences as a teacher in total (i.e., measured as the number of years) does have a negative and similarly strong relation in all the countries. This is somewhat counter-intuitive-i.e., that a longer experience as a teacher should lead to weaker self-efficacy in handling multicultural classrooms. One explanation could be that older, more experienced teachers did not experience these situations initially in their career, as multicultural classrooms were not very prevalent not so many years ago. Consequently, they might not have a significantly longer experience handling multicultural classrooms than their younger colleagues and perhaps mistrust themselves in this situation or do not like it as much as the earlier conditions. Another possibility is that teachers with a long experience, who have not had special preparation in addressing multicultural settings, experience burnout and an inability to cope with the new complex situation. Current research partially supports this explanation (Dubbeld, de Hoog, den Brok, \& de Laat, 2019).

Quality teaching practices have a similar positive relation to self-efficacy in multicultural classrooms across the countries, and student relations as well, although the relationship is weaker. An exception is Denmark, where student relations are not significant in the model, perhaps because of a ceiling effect. Incidentally, the TALIS shows that Denmark has one of the best results in the study concerning studentteacher relations (OECD, 2019a) while also having most classes with multicultural students.

Additionally, the sum of diversity in the classroom appears to have a positive relation to self-efficacy in a multicultural setting across all the countries. The effect is not large, but it does indicate that as teachers get more diverse student groups, they master the situation better and therefore perceive that they can handle a multicultural setting better than those used to smaller diversity. The finding corresponds well with earlier research where exposure to a multicultural situation appears to increase positive attitudes towards this situation (Glock et al., 2019).

However, there are a few inconsistencies in the model, at least from the perspective of a common Nordic model. Workload stress has a negative effect only in three of the five countries. In Finland and Denmark, this effect was found as insignificant, perhaps indicating that the general workload of teachers in these two countries might be lower than in the other three (Carlgren \& Klette, 2008). The same goes for 
the need for professional development for diversity, which has no relation to selfefficacy in multicultural classrooms in Iceland and Finland. Only a small negative relation was observed in the other three countries. This might be because immigration has historically been mostly low in Iceland and Finland compared to the other three countries. This is considerably different from the situation reported across the OECD countries overall (OECD, 2019a) where teachers, in general, reported a significant need for training in this area.

Job satisfaction has a small positive relation in only two of the countries and disciplinary climate a negative relation only in one country although earlier research indicates that job satisfaction among teachers has a moderately strong relationship to school practices, especially those concerning handling increasing diversity (Aydan, 2016). Therefore, these last variables can perhaps be considered less important than the ones that show a clear relationship to multicultural self-efficacy in all the countries. However, research has again shown that teachers' approaches, attitudes, job satisfaction and efficacy are strongly related (Gutentag, Horenczyk, \& Tatar, 2017). In any case, the results presented here shed some light on a number of important differences between the studied countries, variations which might be worthwhile examining in future investigations.

Finally, it is important to reiterate that the model presented here only explains a part of the variation in self-efficacy in multicultural classrooms-about $20 \%$ on average - and there are certainly other factors that should be considered in future studies. The explanatory value (i.e., R-square) is considerably lower in Denmark than in the other countries, indicating that the multicultural setting in Denmark is perhaps somewhat different from the other four countries. One possible explanation is that Denmark has a considerably longer history of multiculturalism in education than all the other countries. However, what is different there will be addressed another time. Still, the historical development of the school systems in the Nordic countries during the last decades has not been aligned, and possible explanatory factors could be found in the different ways these educational systems evolved over time.

\subsubsection{Limitations of the Study}

As mentioned before, the TALIS data has a unique pattern of missing data in the constructs and scales measuring culturally sensitive issues. This high number of missing answers might affect the results presented here, although the scaling model attempts to correct for this (OECD, 2019b). There are a few possible explanations for this high amount of missing answers (e.g., uncertain attitudes about multicultural issues or reluctance or uncertainty in discussing these issues), which, to an extent, marks and restricts the conclusions that can be drawn. In addition, the models explored in this study manage to explain only a part of the variation in selfefficacy in multicultural settings; consequently, the remaining influencing variables should also be identified and studied. Finally, it is also important to mention that the 
differences between the Nordic countries underlined here are primarily because some of the variables related to the SEFE did not reach significance in all the countries. Nevertheless, as in any correlational analysis, a non-significant result does not allow us to conclude that there is no relationship present. The absence of evidence can never be evidence of absence.

\subsection{Conclusions}

One of the main conclusions we can take from the results is that teachers that perceive themselves competent in general and capable of handling most teaching situations in an adequate way (i.e., high teacher efficacy) will probably experience mastery and a higher perception of their own self-efficacy in a multicultural setting as well. This effect appears to strengthen with quality teaching practices. It also seems that having a shorter experience with teaching seems to be an asset, yet further investigation is needed to assess how age and experience mediate the possible views of teachers on multicultural issues in the classroom. Exposure to multicultural classes seems to generate more positive teacher attitudes towards diverse ethnic groups and probably leads to a better class climate and a better learning environment, although some type of burnout in older, more experienced teachers could also be a factor that diminishes the teachers' efficacy in such a setting (Gutentag et al., 2017).

It remains to be seen whether these results strengthen or weaken the concept of a common Nordic school model, as in this simple analysis, there do appear to be considerable differences that do not support a homogeneous pattern in these countries. However, the results still indicate that general high teacher capability and high teacher efficacy should be the essential ingredients in ensuring high equity in the Nordic classrooms. Nonetheless, it is very important to discriminate here between equity and equality; one might suspect that the Nordic countries have done a good job ensuring equality but may have fallen somewhat short in also ensuring equity. This last consideration indicates that minorities and students with different cultural backgrounds could benefit from individualised assistance and instruction. While the practice is established in some schools and classrooms, this is certainly not the case in all of them, thus hindering equity in practice. An awareness of the requirements of an equitable learning environment for all is therefore probably still something that can be improved in all the Nordic countries.

There are, of course, methodological barriers to doing an analysis of this type. The largest one is perhaps the teachers' reluctance to answer questions about multicultural issues, as evidenced by the large number of missing answers to these questions. The over $40 \%$ missing data from Iceland evidently supports this, in addition to the significantly large amount of missing answers from the other countries. Teachers do not have any problems answering factual questions about their work, about their schools or their education and professional development. Still, a significant number of them do not answer questions about diversity and multicultural 
issues. These teachers certainly include those that have a considerable number of multicultural or minority students, so a further exploration of why they do not answer needs to be undertaken. It is not enough to methodologically and statistically account for missing values in the models employed, as is done with the TALIS scaling methods. These teachers' reluctance to answer questions about culturally sensitive issues and how it affects what happens in the classrooms must be better understood. Do the teachers skip questions they are unsure about, are they reluctant to answer them for some other reason or do they simply not know the answers? This must be explored further, perhaps with more concrete teacher items that are as free from value judgements as possible.

Therefore, the main conclusion of this chapter appears to be that if a teacher is competent in what they do, uses appropriate and effective methods in everyday practice, and is supported by their school and colleagues, they will most probably be able to handle a multicultural situation adequately. In addition, one could add that a good teacher most probably knows that they are doing a good job, something that most probably reflects positively on their students.

\section{Appendices}

\section{Appendix 1}

Table 4.8 Reports the Percentage of Teachers Who Have a Certain Proportion of Students of Each Type. For Example, $43 \%$ of the Teachers in Denmark Report That the First Language of Between 1 and 10\% of Their Students is Different from Danish

Table 4.8 Questions about diversity in the class (percentages rounded to whole numbers)

\begin{tabular}{|c|c|c|c|c|c|c|}
\hline \multirow{6}{*}{$\begin{array}{l}\text { Percentage of students whose first } \\
\text { language is different from the } \\
\text { language of instruction }\end{array}$} & & Denmark & Finland & Iceland & Norway & Sweden \\
\hline & None & 37 & 50 & 23 & 26 & 15 \\
\hline & $1-10 \%$ & 43 & 35 & 53 & 51 & 44 \\
\hline & $11-30 \%$ & 12 & 9 & 18 & 16 & 21 \\
\hline & $31-60 \%$ & 5 & 3 & 3 & 3 & 9 \\
\hline & $\begin{array}{l}\text { More } \\
\text { than } 60 \%\end{array}$ & 4 & 3 & 3 & 3 & 11 \\
\hline \multirow{5}{*}{$\begin{array}{l}\text { Percentage of students who are low } \\
\text { academic achievers }\end{array}$} & None & 3 & 6 & 5 & 2 & 3 \\
\hline & $1-10 \%$ & 43 & 42 & 45 & 37 & 42 \\
\hline & $11-30 \%$ & 39 & 36 & 36 & 46 & 34 \\
\hline & $31-60 \%$ & 10 & 8 & 8 & 10 & 12 \\
\hline & $\begin{array}{l}\text { More } \\
\text { than } 60 \%\end{array}$ & 5 & 8 & 6 & 4 & 7 \\
\hline
\end{tabular}


Table 4.8 (continued)

\begin{tabular}{|c|c|c|c|c|c|c|}
\hline \multirow{6}{*}{$\begin{array}{l}\text { Percentage of students whose first } \\
\text { language is different from the } \\
\text { language of instruction }\end{array}$} & & Denmark & Finland & Iceland & Norway & Sweden \\
\hline & None & 37 & 50 & 23 & 26 & 15 \\
\hline & $1-10 \%$ & 43 & 35 & 53 & 51 & 44 \\
\hline & $11-30 \%$ & 12 & 9 & 18 & 16 & 21 \\
\hline & $31-60 \%$ & 5 & 3 & 3 & 3 & 9 \\
\hline & $\begin{array}{l}\text { More } \\
\text { than } 60 \%\end{array}$ & 4 & 3 & 3 & 3 & 11 \\
\hline \multirow{5}{*}{$\begin{array}{l}\text { Percentage of students with special } \\
\text { needs }\end{array}$} & None & 11 & 26 & 11 & 9 & 9 \\
\hline & $1-10 \%$ & 56 & 48 & 49 & 56 & 51 \\
\hline & $11-30 \%$ & 25 & 15 & 28 & 28 & 25 \\
\hline & $31-60 \%$ & 5 & 3 & 6 & 4 & 6 \\
\hline & $\begin{array}{l}\text { More } \\
\text { than } 60 \%\end{array}$ & 4 & 7 & 6 & 3 & 9 \\
\hline \multirow{5}{*}{$\begin{array}{l}\text { Percentage of students with } \\
\text { behavioural problems }\end{array}$} & None & 32 & 17 & 13 & 28 & 19 \\
\hline & $1-10 \%$ & 50 & 47 & 52 & 53 & 54 \\
\hline & $11-30 \%$ & 14 & 26 & 26 & 15 & 18 \\
\hline & $31-60 \%$ & 2 & 7 & 6 & 3 & 4 \\
\hline & $\begin{array}{l}\text { More } \\
\text { than } 60 \%\end{array}$ & 2 & 3 & 3 & 1 & 4 \\
\hline \multirow{5}{*}{$\begin{array}{l}\text { Percentage of students from } \\
\text { socio-economically disadvantaged } \\
\text { homes }\end{array}$} & None & 28 & 24 & 17 & 26 & 22 \\
\hline & $1-10 \%$ & 47 & 48 & 57 & 54 & 48 \\
\hline & $11-30 \%$ & 19 & 21 & 20 & 15 & 18 \\
\hline & $31-60 \%$ & 5 & 5 & 3 & 3 & 7 \\
\hline & $\begin{array}{l}\text { More } \\
\text { than } 60 \%\end{array}$ & 2 & 2 & 2 & 1 & 4 \\
\hline \multirow{5}{*}{$\begin{array}{l}\text { Percentage of students who are } \\
\text { academically gifted }\end{array}$} & None & 3 & 9 & 7 & 2 & 6 \\
\hline & $1-10 \%$ & 14 & 31 & 35 & 20 & 24 \\
\hline & $11-30 \%$ & 28 & 34 & 30 & 26 & 27 \\
\hline & $31-60 \%$ & 35 & 20 & 21 & 31 & 30 \\
\hline & $\begin{array}{l}\text { More } \\
\text { than } 60 \%\end{array}$ & 21 & 6 & 6 & 21 & 13 \\
\hline \multirow{5}{*}{$\begin{array}{l}\text { Percentage of students who are } \\
\text { immigrants or with a migrant } \\
\text { background }\end{array}$} & None & 40 & 51 & 24 & 26 & 14 \\
\hline & $1-10 \%$ & 38 & 34 & 51 & 50 & 42 \\
\hline & $11-30 \%$ & 12 & 10 & 19 & 17 & 23 \\
\hline & $31-60 \%$ & 6 & 4 & 3 & 4 & 9 \\
\hline & $\begin{array}{l}\text { More } \\
\text { than } 60 \%\end{array}$ & 4 & 2 & 3 & 3 & 11 \\
\hline \multirow{5}{*}{$\begin{array}{l}\text { Percentage of students who are } \\
\text { refugees }\end{array}$} & None & 71 & 79 & 76 & 62 & 42 \\
\hline & $1-10 \%$ & 23 & 17 & 21 & 32 & 42 \\
\hline & $11-30 \%$ & 4 & 2 & 2 & 4 & 10 \\
\hline & $31-60 \%$ & 1 & 1 & 1 & 1 & 3 \\
\hline & \begin{tabular}{|l} 
More \\
than 60\%
\end{tabular} & 1 & 1 & 0 & 1 & 3 \\
\hline
\end{tabular}




\section{Appendix 2}

Following is the Data (Percentages of Teachers Who Provided a Certain Answer) That Goes Into the Index of Self-efficacy in Multicultural Classrooms Table 4.9.

Table 4.9 Q 45 In teaching a culturally diverse class, to what extent can you do the following?

\begin{tabular}{|c|c|c|c|c|c|c|}
\hline \multirow{5}{*}{$\begin{array}{l}\text { Cope with the challenges of a } \\
\text { multicultural classroom }\end{array}$} & & Denmark & Finland & Iceland & Norway & Sweden \\
\hline & Not at all & 1 & 0 & 3 & 1 & 1 \\
\hline & $\begin{array}{l}\text { To some } \\
\text { extent }\end{array}$ & 14 & 31 & 36 & 40 & 31 \\
\hline & $\begin{array}{l}\text { Quite a } \\
\text { bit }\end{array}$ & 59 & 51 & 42 & 51 & 51 \\
\hline & A lot & 26 & 17 & 19 & 8 & 17 \\
\hline \multirow{4}{*}{$\begin{array}{l}\text { Adapt my teaching to the cultural } \\
\text { diversity of my students }\end{array}$} & Not at all & 3 & 6 & 8 & 2 & 4 \\
\hline & $\begin{array}{l}\text { To some } \\
\text { extent }\end{array}$ & 29 & 55 & 39 & 54 & 44 \\
\hline & $\begin{array}{l}\text { Quite a } \\
\text { bit }\end{array}$ & 52 & 29 & 38 & 38 & 40 \\
\hline & A lot & 15 & 10 & 15 & 6 & 13 \\
\hline \multirow{4}{*}{$\begin{array}{l}\text { Ensure that students with and } \\
\text { without a migrant background work } \\
\text { together }\end{array}$} & Not at all & 2 & 6 & 3 & 1 & 2 \\
\hline & $\begin{array}{l}\text { To some } \\
\text { extent }\end{array}$ & 12 & 25 & 28 & 31 & 28 \\
\hline & $\begin{array}{l}\text { Quite a } \\
\text { bit }\end{array}$ & 48 & 41 & 40 & 53 & 45 \\
\hline & A lot & 37 & 28 & 29 & 15 & 25 \\
\hline \multirow{4}{*}{$\begin{array}{l}\text { Raise awareness for cultural } \\
\text { differences amongst students }\end{array}$} & Not at all & 2 & 9 & 3 & 4 & 4 \\
\hline & $\begin{array}{l}\text { To some } \\
\text { extent }\end{array}$ & 17 & 47 & 33 & 47 & 38 \\
\hline & $\begin{array}{l}\text { Quite a } \\
\text { bit }\end{array}$ & 53 & 31 & 44 & 42 & 42 \\
\hline & A lot & 28 & 12 & 20 & 7 & 16 \\
\hline \multirow{4}{*}{$\begin{array}{l}\text { Reduce ethnic stereotyping amongst } \\
\text { students }\end{array}$} & Not at all & 2 & 4 & 3 & 3 & 3 \\
\hline & $\begin{array}{l}\text { To some } \\
\text { extent }\end{array}$ & 13 & 39 & 25 & 40 & 33 \\
\hline & $\begin{array}{l}\text { Quite a } \\
\text { bit }\end{array}$ & 52 & 37 & 47 & 46 & 43 \\
\hline & A lot & 32 & 21 & 25 & 12 & 21 \\
\hline
\end{tabular}

Note. All percentages were rounded to whole numbers 


\section{References}

Agasisti, T., Avvisati, F., Borgonovi, F., \& Longobardi, S. (2018). Academic resilience: What schools and countries do to help disadvantaged students succeed in PISA. Paris: OECD Publishing.

Ainley, J., \& Carstens, R. (2018). Teaching and Learning International Survey (TALIS) 2018 Conceptual Framework. (OECD Education Working Papers, No. 187). OECD Publishing.

$\mathrm{Au}$, K. H., \& Raphael, T. E. (2000). Equity and literacy in the next millennium. Reading Research Quarterly, 35(1), 170-188. https://doi.org/10.1598/rrq.35.1.12

Aydan, O. (2016). The effects of diversity management on job satisfaction and individual performance of teachers. Educational Research and Reviews, 11(3), 105-112. https://doi. org/10.5897/ERR2015.2573

Brante, G. (2009). Multitasking and synchronous work: Complexities in teacher work. Teaching and Teacher Education, 25(3), 430-436. https://doi.org/10.1016/j.tate.2008.09.015

Carlgren, I., \& Klette, K. (2008). Reconstructions of Nordic teachers: Reform policies and teachers' work during the 1990s. Scandinavian Journal of Educational Research, 52(2), 117-133. https://doi.org/10.1080/00313830801915754

Cushner, K., \& Brennan, S. (Eds.). (2007). Intercultural student teaching: A bridge to global competence. Lanham, MD: Rowman \& Littlefield Education.

Dubbeld, A., de Hoog, N., den Brok, P., \& de Laat, M. (2019). Teachers' attitudes toward multiculturalism in relation to general and diversity-related burnout. European Education, 51(1), 16-31. https://doi.org/10.1080/10564934.2017.1401435

Espinoza, O. (2007). Solving the equity-equality conceptual dilemma: a new model for analysis of the educational process. Educational Research, 49(4), 343-363. https://doi. org/10.1080/00131880701717198

Fauth, B., Decristan, J., Rieser, S., Klieme, E., \& Büttner, G. (2014). Student ratings of teaching quality in primary school: Dimensions and prediction of student outcomes. Learning and Instruction, 29(29), 1-9. https://doi.org/10.1016/j.learninstruc.2013.07.001

Geerlings, J., Thijs, J., \& Verkuyten, M. (2019). Preaching and practicing multicultural education: Predicting students' outgroup attitudes from perceived teacher norms and perceived teacherclassmate relations. Journal of School Psychology, 75, 89-103. https://doi.org/10.1016/j. jsp.2019.07.003

Geiser, C. (2013). Data analysis with MPLUS. New York: The Guilford Press.

Glock, S., Kovacs, C., \& Pit-ten Cate, I. (2019). Teachers' attitudes towards ethnic minority students: Effects of schools' cultural diversity. British Journal of Educational Psychology, 89(4), 616-634. https://doi.org/10.1111/bjep.12248

Gustafsson, J.-E., Nilsen, T., \& Hansen, K. Y. (2016). School characteristics moderating the relation between student socioeconomic status and mathematics achievement in grade 8 . Evidence from 50 countries in TIMSS 2011. Studies in Educational Evaluation, 57. https://doi. org/10.1016/j.stueduc.2016.09.004

Gutentag, T., Horenczyk, G., \& Tatar, M. (2017). Teachers' approaches toward cultural diversity predict diversity-related burnout and self-efficacy. Journal of Teacher Education, 69(4), 408-419. https://doi.org/10.1177/0022487117714244

Hamre, B. K., Pianta, R. C., Downer, R. C., DeCoster, J., Mashburn, A. J., Jones, S. M., et al. (2013). Teaching through interactions: Testing a developmental framework of teacher effectiveness in over 4,000 classrooms. The Elementary School Journal, 113(4), 461-487. https:// doi.org/10.6027/ANP2018-74210.1086/669616

IEA. (2019). IDB Analyzer. https://www.iea.nl/data-tools/tools\#section-308

Imsen, G., Blossing, U., \& Moos, L. (2017). Reshaping the Nordic education model in an era of efficiency. Changes in the comprehensive school project in Denmark, Norway, and Sweden since the millennium. Scandinavian Journal of Educational Research, 61(5), 568-583.

Jenkins-Martin, T. (2014). The role of culturally responsive teaching, multicultural education and teacher self-efficacy: Am I reaching my students? Doctoral dissertation, UC San Diego. 
ProQuest ID: JenkinsMartin_ucsd_0033D_14065. Merritt ID: ark:/20775/bb49845065. https:// escholarship.org/uc/item/6791s6vn

Karlsdottir, A., Norlen, G., Rispling, L., \& Randall, L. (Eds.). (2018). State of the Nordic region 2018: Immigration and integration edition. Nordic Council of Ministers. https://doi. org/10.6027/ANP2018-742

Klette, K. (2018). Individualism and collectivism in Nordic schools: A comparative approach. In N. Witoszek \& A. Midttun (Eds), Sustainable Modernity: The Nordic Model and Beyond (1st Edn.). London: Routledge. https://doi-org.ezproxy.uio.no/10.4324/9781315195964.

Kunter, M., Klusmann, U., Baumert, J., Richter, D., Voss, T., \& Hachfeld, A. (2013). Professional competence of teachers: Effects on instructional quality and student development. Journal of Educational Psychology, 105(3), 805-820. https://doi.org/10.1037/a0032583

Lundahl, L. (2016). Equality, inclusion and marketisation of Nordic education: Introductory notes. Research in Comparative and International Education, 11(1), 3-12. https://doi. org/10.1177/1745499916631059

Moskal, M., \& Tyrrell, N. (2015). Family migration decision-making, step-migration and separation: children's experiences in European migrant worker families. Children's Geographies, 14(4), 453-467. https://doi.org/10.1080/14733285.2015.1116683

Muthén, L. K., \& Muthén, B. O. (1998-2017). Mplus user's guide (Version 8). Los Angeles, CA: Muthén \& Muthén.

OECD. (2018a). Equity in education: Breaking down barriers to social mobility. Paris: OECD Publishing. https://tinyurl.com/y5pur9sk

OECD. (2018b). The resilience of students with an immigrant background: Factors that shape well-being. Paris: OECD Publishing. https://tinyurl.com/yyxarm9b

OECD. (2019a). TALIS 2018 results (Volume I): Teachers and school leaders as lifelong learners. Paris: OECD Publishing. https://doi.org/10.1787/1d0bc92a-en

OECD. (2019b). Talis 2018 Technical Report. Paris: OECD Publishing. https://tinyurl.com/ yyfrwepu

Sela-Shayovitz, R., \& Finkelstein, I. (2020). Self-efficacy in teaching multicultural students in academia. International Journal of Higher Education, 9(1), 159.

Spanierman, L. B., Euna, O., Heppner, P. P., Neville, H. A., Mobley, M., Wright, C. V., et al. (2011). The multicultural teaching competency scale: Development and initial validation. Urban Education, 46(3), 440-464. https://doi.org/10.1177/0042085910377442

Stronge, J. H., Ward, T. J., \& Grant, L. W. (2011). What makes good teachers good? A cross-case analysis of the connection between teacher effectiveness and student achievement. Journal of Teacher Education, 62(4), 339-355. https://doi.org/10.1177/0022487111404241

Veenis, J. C. (2014). The Nordic education model: 'A school for all' encounters neo-liberal policy (U. Blossing, G. Imsen, and L. Moos, Eds.). Leadership and Policy in Schools, 16(4), 634-640. https://doi.org/10.1080/15700763.2016.1278247

Wubbels, T., den Brok, P., Veldman, I., \& van Tartwijk, J. (2006). Teacher interpersonal competence for Dutch secondary multicultural classrooms. Teachers and Teaching, 12(4), 407-433. https://doi.org/10.1080/13450600600644269 
Open Access This chapter is licensed under the terms of the Creative Commons Attribution 4.0 International License (http://creativecommons.org/licenses/by/4.0/), which permits use, sharing, adaptation, distribution and reproduction in any medium or format, as long as you give appropriate credit to the original author(s) and the source, provide a link to the Creative Commons license and indicate if changes were made.

The images or other third party material in this chapter are included in the chapter's Creative Commons license, unless indicated otherwise in a credit line to the material. If material is not included in the chapter's Creative Commons license and your intended use is not permitted by statutory regulation or exceeds the permitted use, you will need to obtain permission directly from the copyright holder. 